\title{
Inhibition of Toxic Effects of Viper and Cobra Venom by Indian Medicinal Plants
}

\author{
M. I. Alam \\ Department of Paramedical Sciences, Hamdard Institute of Medical Sciences \& Research, Jamia Hamdard \\ University, New Delhi, India \\ Email: iqbalasc@yahoo.com
}

Received 1 June 2014; revised 3 July 2014; accepted 20 July 2014

Copyright (C) 2014 by author and Scientific Research Publishing Inc.

This work is licensed under the Creative Commons Attribution International License (CC BY).

http://creativecommons.org/licenses/by/4.0/

c) (i) Open Access

\section{Abstract}

The mortality rate from snakebites in West Bengal is very high and most of the deaths are caused by the Daboia russelli and Naja naja envenomation. Twenty-three plants from the seventeen families were collected from the traditional healers and explored for the first time for antisnake venom activity. In our previous report, the methanolic root extract of the Indian medicinal plants Pluchea indica, Hemidesmus indicus, Vitex negundo and Emblica officinalis significantly neutralized the Viper and Cobra venom-induced pathophysiological changes [1] [2]. In the present study, we explored four plant extracts (Curcuma aromatica, Aristolochia indica, Androgrphis paniculata and Curcuma zeodaria) for the antisnake venom activity. The plant extracts significantly antagonized Daboia russelli, Echis carinatus, Ophiophagus hannah and Naja kaouthia venom-induced lethal activity both in in vitro and in vivo studies. Daboia russellii venom-induced haemorrhage, coagulant, defibrinogenating and $P L A_{2}$ activity were significantly neutralized by the extracts. No precipitating bands were observed between the plant extract and venom. This observation confirmed the role of active constituents of plants and plant materials involved in snake venom inhibition. Further studies are going on in our laboratory for the identification of active molecules as well as their mechanism of venom inhibition.

\section{Keywords}

Anti-Snake Venom Activity, Medicinal Plants, Snake Venom

\section{Introduction}

Every year more than 100,000 people die due to snakebite worldwide. In India morality rate is very high, 40,000 - 50,000 die annually [3] [4]. Daboia russelli, Echis carinatus, Naja kaouthia and Naja naja are the common 
snakes found throughout India and a large number of deaths occur due to envenomation by these snakes. The antiserum is the only therapeutic agent available for the treatment of snakebite and does not provide enough protection against venom inducing haemorrhage, necrosis, nephrotoxicity and often produces hypersensitive reactions [5]-[7]. Antiserum development in animal is time consuming, expensive and requires ideal storage condition. Monovalent antiserum is not available and the health center is usually far and few in number. To overcome these drawbacks, there is a great need to search, to develop new affordable and suitable antidote against snakebite.

The World Health Organization estimates that $80 \%$ of the world's population depends on traditional medicine for their primary health care needs. As long as man can remember, plants/plant materials have been used worldwide in traditional medicine for the treatment of different diseases. It is estimated that even today approximately seventy percent of the world population rely on medicinal plants as their primary source of medicines [8]. Till today many of the drugs used are derived from natural products or are dependent upon natural products for the development. In the recent discoveries of the analgesic, anti-arthritis, antimicrobial and anticancer agent (taxol) indicate the continuing importance of plant species in drug discovery. Currently, a large number of plants and plant materials are being screened for pharmacological activities especially those used in traditional/folk medicine against different diseases. Over the years, many attempts have been made for the development of snake venom antagonists especially from plant sources in spite of the existence of antiserum. Many Indian medicinal plants/plant materials are recommended for the treatment of snakebite [2] [9] [10] and some are tested, but so far no systematic analysis has been done. In our earlier studies, it was showed that four of these plants (Table 1), successfully neutralized the venom-induced pathophysiological changes [1] [2]. The present investigation attempts to identify those species, which are used in folk medicine in West Bengal, India and are worthy of further investigation as leads for drug development in management of snake bite.

\section{Materials and Methods}

\subsection{Venom}

Lyophilized snake venom of Daboia russelli, Echis carinatus, Ophiophagus hannah and Naja kaouthia were obtained from Calcutta snake park, Kolkata, India and were preserved in a desiccator at $4^{\circ} \mathrm{C}$ for further use. It was dissolved in $0.9 \%$ saline and centrifuged at $2000 \mathrm{rpm}$ for $10 \mathrm{~min}$. The solution was used as venom and was stored at $4^{\circ} \mathrm{C}$ until further use. Venom concentration was expressed in terms of dry weight.

\subsection{Plant Extracts}

Plants/plant materials were obtained from different places of West Bengal after being indicated by traditional healer and then they were identified by Dr. N. Paria, Department of Botany, University of Calcutta, West Bengal. Some of these plants were also purchased commercially from M/s United chemical and Allied products, Kolkata, and processed in the following manner.

After drying and crushing individual sample of the relevant parts of each plant species, was extracted first by refluxing with petroleum ether $\left(50^{\circ} \mathrm{C}-60^{\circ} \mathrm{C}\right.$, for $\left.72 \mathrm{~h}\right)$ and then by methanol $\left(60^{\circ} \mathrm{C}-80^{\circ} \mathrm{C}\right.$ for $\left.72 \mathrm{~h}\right)$. Methanol extract was concentrated in vaccuo and kept in a desiccator at room temperature for further use. Before use, it was dissolved in saline and centrifuged at $2000 \mathrm{rpm}$ for $10 \mathrm{~min}$ at room temperature. The solution was used for further investigation and kept at $4^{\circ} \mathrm{C}$. The plant extracts were expressed in terms of dry weight.

\subsection{Snake Venom Antiserum}

Lyophilized polyvalent snake venom antiserum (as reference serum) was obtained from Bengal chemicals and pharmaceuticals Private Ltd. Kolkata. Before use antiserum was dissolved in $0.9 \%$ saline.

\subsection{Animals}

Male albino mice of body weight about 18 - $20 \mathrm{~g}$ were used in this study after acclimatization to the laboratory condition. The study plan was approved by the Animal Ethics Committee of University of Calcutta, Kolkata; India. All animals were cared for and handled in accordance with the guideline of the ethical committee. 
Table 1. Medicinal plants used by traditional healer against snake bites were tested in laboratory against snake venoms in experimental rodents.

\begin{tabular}{|c|c|c|c|}
\hline Family and species & Parts used & Source & Antisnake venom activity (present study) \\
\hline \multicolumn{4}{|l|}{ 1. Acanthaceae } \\
\hline Andrographis paniculata Nees & Root & Medicineman and Literature & Present \\
\hline Rhinacanthus communis Nees & Root & Medicineman & Absent \\
\hline \multicolumn{4}{|l|}{ 2. Amaranthaceae } \\
\hline Achyranthes aspera linn. & Root & Medicineman & Absent \\
\hline \multicolumn{4}{|l|}{ 3. Aristolochiaceae } \\
\hline Aristolochia indica linn. & Root & Medicineman and Literature & Present \\
\hline 4. Asteraceae (compositae) & Aerial parts & Medicineman & Absent \\
\hline \multicolumn{4}{|l|}{ Eclipta alba (L.) Hassk } \\
\hline \multicolumn{4}{|l|}{ Syn. Eclipta prostrata (L.L.) } \\
\hline Eupatorium triplinerve Vahl & Leaf & Medicineman & Absent \\
\hline \multicolumn{4}{|l|}{ Syn. Eupatorium ayapana Vent. } \\
\hline *Pluchea indica (L.) Less & Root & Medicineman & Present \\
\hline \multicolumn{4}{|l|}{ 5. Cururbitaceae } \\
\hline Trichosanthes dioica Roxb & Root & Literature & Absent \\
\hline \multicolumn{4}{|l|}{ 6. Crasulaceae } \\
\hline Kalanchae pinnata (Lamk.) Pers & Root & Literature & Absent \\
\hline \multicolumn{4}{|l|}{ Syn. Bryphyllum calycinum } \\
\hline \multicolumn{4}{|l|}{ 7. Cyperaceae } \\
\hline Kyllinga nemoralis (J.R.et G. Forster) & Whole body & Medicineman & Absent \\
\hline \multicolumn{4}{|l|}{ Dandy ex Hutchinson Dalziel } \\
\hline \multicolumn{4}{|l|}{ Syn. Kyllinga monocephala Rottb. } \\
\hline \multicolumn{4}{|l|}{ Syn. Cyperas kylling Endle. } \\
\hline \multicolumn{4}{|l|}{ 8. Euphrobiaceae } \\
\hline Ricinus communis L. & Root & Medicineman & Absent \\
\hline *Embilica officinalis Gaertn & Root & Medicineman & Present \\
\hline \multicolumn{4}{|l|}{ 9. Fabaceae } \\
\hline Albizzia lebbeck (L.) Beath & Stem Bark & Literature & Absent \\
\hline \multicolumn{4}{|l|}{ 10. Lamiaceae (Labiatae) } \\
\hline Leucas lavandulifolia Sm. & Leaf & Medicineman and Literature & Absent \\
\hline \multicolumn{4}{|l|}{ 11. Menispermaceae } \\
\hline Stephania japonica (Thunb.) Miers & Root & Medicineman & Absent \\
\hline \multicolumn{4}{|l|}{ Syn. Stephania heamandifolia (Wild) Wslp } \\
\hline \multicolumn{4}{|l|}{ 12. Moringaceae } \\
\hline \multicolumn{4}{|l|}{ Syn. Moringa oleifera (Lamk) } \\
\hline \multicolumn{4}{|l|}{ 13. Molluginaceae } \\
\hline Glinus oppositifoilius L. & Whole body & Medicineman & Absent \\
\hline \multicolumn{4}{|l|}{ Syn. Mollugo spergula (Linn.) } \\
\hline 14. Periplocaceae & & & \\
\hline *Hemidesmus indicus (L.) R.Br. & Root & Literature & Present \\
\hline Syn. Periploca indica (L.) & & & \\
\hline 15. Theaceae & & & \\
\hline Camellia sianensis (Linn.) Kuntz & Root & Medicineman & Absent \\
\hline 16. Verbenaceae & & & \\
\hline *Vitex negundo Linn. & Root & Medicineman and Literature & Present \\
\hline 17. Zingiberaceae & & & \\
\hline Curcuma aromatica Salisb & Root & Medicineman and Literature & Present \\
\hline Curcuma zedoaria Rox & Root & Medicineman & Present \\
\hline Curcuma longa Linn. & Root & Medicineman & Absent \\
\hline
\end{tabular}

*Plant possess anti-snake venom activity as reported earlier (Alam and Gomes, 2003; Alam et al., 1996). 


\subsection{Inhibition of Venom Lethal Effect}

The toxicity of snake venom was assessed by injection of different concentration of venom in $0.2 \mathrm{ml}$ physiological saline into tail vein of male albino mice 18 - 20 gm [1]. To assess the in vitro antagonism, various concentrations of venom $\left(1-300 \mathrm{LD}_{50}\right)$ were mixed with a fixed amount of plant extract $(2 \mathrm{mg})$, the mixture incubated at $37^{\circ} \mathrm{C}$ for $1 \mathrm{~h}$, and centrifuged at $2000 \mathrm{rpm}$ for $10 \mathrm{~min}$. The supernatant was injected intravenously into male albino mice (18 - $20 \mathrm{~g}$ ), ten mice per dose. The median lethal dose $\left(\mathrm{LD}_{50}\right)$ was calculated $24 \mathrm{~h}$ after injection of the venom-extract mixture. Lethal toxicity was also assessed by subcutaneously injection of various doses of venom. The neutralizing potency of each plant extract was assessed by s.c injection of venom $\left(1-5 L_{50}\right)$ into groups of ten mice followed by immediate injection of fixed dose of plant extract (5 mg) orally (p.o.).

\subsection{Inhibition of Venom Haemorrhagic Activity}

The minimum haemorrhagic dose (MHD) of venom (defined as the least amount of venom which when injected intradermaly (i.d) into mice results in a haemorrhagic lesion of $10 \mathrm{~mm}$ diameter $24 \mathrm{~h}$ later was measured [11]. Neutralization of the haemorrhagic activity was estimated by mixing a fixed amount of plant extract $(2 \mathrm{mg})$ with different amounts of venom ( 1 - 300 MHD). The plant extract-venom mixture was incubated at $37^{\circ} \mathrm{C}$ for $1 \mathrm{~h}$, centrifuged at $2000 \mathrm{rpm} \times 10 \mathrm{~min}$, and $0.1 \mathrm{ml}$ of supernatant injected (i.d). The haemorrhagic lesion was estimated after $24 \mathrm{~h}$. To assess the antihaemorrhagic activity of venom in vivo, various amount of venom $(1-6$ MHD) were injected (i.d) followed immediately by the plant extract (5 mg, p.o.) and the haemorrhagic lesion measured after $24 \mathrm{~h}$.

\subsection{Inhibition of Venom Coagulant Activity}

The minimum clotting dose of plasma (MCDP) was determined as described by Alam et al. [1]. Neutralization of this activity was estimated by mixing different amount of venom (1 - 200 MCD), with a fixed amount of plant extract $(100 \mu \mathrm{g})$, incubating for $1 \mathrm{~h}$ at $37^{\circ} \mathrm{C}$. Different concentration of incubate were added to the experimental tube in place of $0.1 \mathrm{ml}$ physiological saline, and the clotting time was recorded.

\subsection{Inhibition of Venom Serum Inhibitory Activity}

Inhibition of snake venom serum activity was measured in order to examine if the decreased clotting of $V$. russellii venom on goat plasma was due to venom inhibition in serum. Goat blood was collected without anticoagulant, incubated in glass tubes for $2 \mathrm{~h}$ at $37^{\circ} \mathrm{C}$ and then centrifuged at $2000 \mathrm{rpm}$ for $15 \mathrm{~min}$. Pooled sera were kept frozen at $-20^{\circ} \mathrm{C}$. Equal volumes of Tyrode-Hepes buffer $\left(137 \mathrm{mM} \mathrm{Nacl} ; 2.7 \mathrm{mM} \mathrm{KCl} ; 12 \mathrm{mM} \mathrm{NaHCO} \mathrm{O}_{3}\right.$, $0.42 \mathrm{mM} \mathrm{NaH}_{2} \mathrm{Po}_{4}, 10 \mathrm{mM}$ Hepes; $\mathrm{pH}$ 7.4) or goat serum was incubated with venom solution of different concentration for $5 \mathrm{~min}$ at $37^{\circ} \mathrm{C}$. Aliquots of $50 \mu \mathrm{l}$ were then added to $200 \mu \mathrm{l}$ of goat serum (maintained for $2 \mathrm{~min}$ at $37^{\circ} \mathrm{C}$ ) and the clotting time recorded. MCDS were then calculated. Neutralization of serum inhibitory activity was estimated by mixing different amount of venom with fixed amount of plant extract, incubating for $1 \mathrm{~h}$ at $37^{\circ} \mathrm{C}$ and centrifuged. Supernatant was then added to the experimental group and the clotting time was observed.

\subsection{Inhibition of Venom Defibrinogenating Activity}

Minimum defibrinogenating dose (MDD) of $V$. russellii venom is defined as the minimum amount of venom which when injected i.v into mice causes' incoagulable blood $1 \mathrm{~h}$ later [1]. Neutralization of this activity was estimated by mixing different amount of venom with fixed amounts of plant extract, incubating at $37^{\circ} \mathrm{C}$ for $1 \mathrm{~h}$, and centrifuge at $3000 \mathrm{rpm}$ at 5 minutes. The supernatant was injected $i . v$ into albino mice (18 - $20 \mathrm{~g})$ as described above. For in vivo studies, the MDD of venom was injected i.v followed by the plant extract (p.o.) and the nature of the blood observed after $1 \mathrm{~h}$.

The neutralization ability of plant extracts was expressed as effective dose $50\left(E D_{50}\right)$ defined as the amount of plant extract at which the venom induced (lethal and haemorrhagic) action was reduced by 50\%. The effective dose (ED) was defined as the amount of plant extract at which the venom induced MCDP and MDD activities were effectively neutralized.

\subsection{Inhibition of Venom PLA 2 Effect}

For PLA $A_{2}$ activity experiments, egg yolk (obtained from commercially available eggs), 0.5\% EDTA, $50 \mathrm{mM}$ 
Tris HCl buffer (pH 7.5), 2\% sodium chloride, $1 \%$ calcium chloride and $0.9 \%$ sodium chloride from Sigma except otherwise stated were used.

For carrying out the experiment, $2.0 \mathrm{ml}$ of egg yolk suspension and $0.2 \mathrm{ml}$ of test material (venom or venom compound) were mixed in the test tube and incubated at $37^{\circ} \mathrm{C}$ for $1 \mathrm{~h}$. After incubation the time required for coagulation of egg yolk was recorded by placing the test tube containing test materials on the boiling water bath. A blank was run with normal saline instead of test material. One unit enzyme activity was defined as the amount of venom, which increased the coagulation time of the egg yolk control by one minute.

Neutralization of the enzyme activity was estimated on the different amount of plant extract mixed with the different amount of viper venom. The venom-extract mixture was incubated at $37^{\circ} \mathrm{C}$ for $1 \mathrm{~h}$. Centrifuged at 2000 rpm for 10 min, supernatant was tested in a total of $0.2 \mathrm{ml}$ for the enzyme neutralization activity.

\subsection{Immunological Interaction of Venom and Plant Extracts}

To assess the immunological interaction of venom and plant extract, immunogel diffusion [12] and immunogel electrophoresis [13] were performed.

\subsection{Statistical Analysis}

All results are expressed as Mean \pm SE. The significance of the difference between mean was determined by student's t test. All assays were performed ten times.

\section{Results}

$\mathrm{LD}_{50}$ of Doboia russellii venom was $2.2 \mu \mathrm{g}$ per mouse (i.v), $45 \mu \mathrm{g}$ per mouse (s.c), Echis carinatus venom 1.58 $\mu \mathrm{g}$ per mouse (i.v), $25.19 \mu \mathrm{g}$ per mouse (s.c), Ophiophagus hannah venom was $2 \mu \mathrm{g}$ per mouse (i.v), $2.51 \mu \mathrm{g}$ per mouse (s.c) and Naja kaouthia venom was $2.8 \mu$ g per mouse (i.v), $4.61 \mu \mathrm{g}$ per mouse (s.c). The MHD was $5 \mu \mathrm{g}$ per mouse of Daboia russelli venom and $2 \mu \mathrm{g}$ per mouse of Echis carinatus venom. MCDP/MCDS $1 \mu \mathrm{g} / \mathrm{ml}$, $\mathrm{PLA}_{2}$ was $2 \mu \mathrm{g}$ and MDD was $2.5 \mu \mathrm{g}$ per mouse of Daboia russelli venom. Both plant extracts (up to $1 \mathrm{mg} / \mathrm{kg}$, i.v) did not produce lethal effect up to $48 \mathrm{~h}$ of observation.

Through collection from different rural places of West Bengal and identification, twenty three plants/plant materials of seventeen families were examined for anti-snake venom activity. Eight plant materials were found to be active against snake bite (Table 2). In the present paper only four plants those are not reported earlier were taken for anti-snake venom activity. The plant extracts (up to $1 \mathrm{mg} / \mathrm{kg}, i . v$ ) did not produce lethal effect.

Table 2. Neutralization of lethal action of Daboia russellii and Echis carinatus venom by plant extracts in male albino mice.

\begin{tabular}{|c|c|c|c|c|c|c|}
\hline Extract (mg) & $\begin{array}{l}\text { D. russellii } \\
\text { Venom }(\mu \mathrm{g})\end{array}$ & $\begin{array}{l}\text { Fold of neutralization } \\
\qquad\left(\mathrm{LD}_{50}\right)\end{array}$ & $* \mathrm{ED}_{50}(\mathrm{mg})$ & $\begin{array}{l}\text { E. carinatus } \\
\text { venom }(\mu \mathrm{g})\end{array}$ & $\begin{array}{l}\text { Fold of neutralization } \\
\qquad\left(\mathrm{LD}_{50}\right)\end{array}$ & $\mathrm{ED}_{50}(\mathrm{mg})$ \\
\hline \multicolumn{7}{|c|}{ Venom extracts incubated $370^{\circ} \mathrm{C} / 60 \mathrm{~min}$ and injected i.v } \\
\hline C. aromatica (2) & 45 & 20.5 & $0.21 \pm 0.01$ & 50 & 31.6 & $0.22 \pm 0.01$ \\
\hline A. indica (2) & 25 & 11.4 & $0.22 \pm 0.01$ & 12 & 07.6 & $0.31 \pm 0.02$ \\
\hline A. paniculata (2) & 25 & 11.4 & $0.31 \pm 0.01$ & 06 & 03.8 & $0.53 \pm 0.02$ \\
\hline C. zedoaria (2) & 15 & 06.8 & $0.53 \pm 0.02$ & 06 & 03.8 & $0.61 \pm 0.01$ \\
\hline \multicolumn{7}{|c|}{ Venom injected (s.c) ${ }^{* *}$ followed immediately by extract, p.o. } \\
\hline C. aromatica (5) & 180 & 4 & $2.6 \pm 0.22$ & 100 & 3.96 & $2.7 \pm 0.20$ \\
\hline A. indica (5) & 090 & 2 & $2.7 \pm 0.20$ & 060 & 2.38 & $2.6 \pm 0.21$ \\
\hline A. paniculata (5) & 090 & 2 & $2.8 \pm 0.22$ & 060 & 2.38 & $2.5 \pm 0.22$ \\
\hline C. zedoaria (5) & 090 & 2 & $2.8 \pm 0.23$ & 050 & 1.98 & $2.7 \pm 0.22$ \\
\hline
\end{tabular}

*Defined as the effective dose of plant extract which neutralized venom dose of $2 \mathrm{LD}_{50}$ in vitro/2LD $\mathrm{L}_{50}$ in vivo. Results are expressed as mean of ten observations. ${ }^{* *}$ Duration of deaths time following venom exposure: Daboia russellii venom (1 Minimum lethal dose) = $13.24 \pm 0.30$ hours; Echis carinatus venom (1 Minimum lethal dose $)=12.20 \pm 0.30$ hours. 


\subsection{Lethal Activity}

In in vitro study, viper venom (1 - $\left.50 \mathrm{LD}_{50}\right)$ was incubated with plant extracts $(2 \mathrm{mg})$ and gave protection against venom-induced lethality. In in vivo study, viper venom $\left(1-6 L_{50}\right)$ was injected s.c into male albino mice followed by the plant extracts (5 mg/mouse, p.o.). Daboia russellii, Echis carinatus, Ophiophagus hannah and Naja kaouthia venom induced lethality was significantly antagonized by the plant extracts (Table 2 \& Table 3). The $\mathrm{ED}_{50}$ of the plant extracts of $C$. aromatica, A. indica, A. paniculata and C. zeodaria were found to be 0.21 $\mathrm{mg}, 0.22 \mathrm{mg}, 0.31 \mathrm{mg}, 0.53 \mathrm{mg}$ in vitro and $2.6 \mathrm{mg}, 2.7 \mathrm{mg}, 2.8 \mathrm{mg}, 2.8 \mathrm{mg}$ respectively in in vivo against $D a-$ boia russelli venom (Table 2).

\subsection{Haemorrhagic Activity}

In in vitro study, venom (1 - 10 MHD) incubated with extract (2 mg) and injected (i.d) into mice, gave protection against venom induced haemorrhagic activity (Table 4). In in vivo study, venom (1 - 2 MHD) injected (i.d) into mice followed by plant extracts ( $5 \mathrm{mg}$, p.o.), gave protection against venom induced haemorrhagic activity. The degree of protection in in vivo was less than that of in vitro. Effective dose of C. aromatica, A. indica, A. paniculata and C. zeodaria were found to be $0.25 \mathrm{mg}, 0.26 \mathrm{mg}, 0.35 \mathrm{mg}, 0.34 \mathrm{mg}$ in vitro and $2.5 \mathrm{mg}, 2.6 \mathrm{mg}$, $2.5 \mathrm{mg}, 2.7 \mathrm{mg}$ respectively in vivo against Daboia russellii venom (Table 4).

Table 3. Neutralization of lethal action of Naja kaouthia and Ophiophagus hannah venom by plant extracts in male albino mice.

\begin{tabular}{|c|c|c|c|c|c|c|}
\hline Extract (mg) & $\begin{array}{l}\text { N. kauthia } \\
\text { Venom }(\mu \mathrm{g})\end{array}$ & $\begin{array}{l}\text { Fold of neutralization } \\
\qquad\left(L_{50}\right)\end{array}$ & $* \mathrm{ED}_{50}(\mathrm{mg})$ & $\begin{array}{c}\text { O. hannah } \\
\text { venom }(\mu \mathrm{g})\end{array}$ & $\begin{array}{l}\text { Fold of neutralization } \\
\qquad\left(L_{50}\right)\end{array}$ & $\mathrm{ED}_{50}(\mathrm{mg})$ \\
\hline \multicolumn{7}{|c|}{ Venom extracts incubated $370^{\circ} \mathrm{C} / 60 \mathrm{~min}$ and injected i.v } \\
\hline C. aromatica (2) & 18 & 6.4 & $0.32 \pm 0.01$ & 14 & 7 & $0.41 \pm 0.02$ \\
\hline A. indica (2) & 12 & 4.3 & $0.41 \pm 0.01$ & 06 & 3 & $0.51 \pm 0.01$ \\
\hline A. paniculata (2) & 06 & 2.1 & $0.61 \pm 0.02$ & 06 & 3 & $0.61 \pm 0.01$ \\
\hline C. zedoaria (2) & 06 & 2.1 & $0.65 \pm 0.01$ & 06 & 3 & $0.62 \pm 0.01$ \\
\hline \multicolumn{7}{|c|}{ Venom injected (s.c) ** followed immediately by extract, p.o. } \\
\hline C. aromatica (5) & 18 & 4.0 & $2.7 \pm 0.21$ & 12 & 4.78 & $2.7 \pm 0.22$ \\
\hline A. indica (5) & 10 & 2.1 & $2.6 \pm 0.15$ & 06 & 2.39 & $2.7 \pm 0.21$ \\
\hline A. paniculata (5) & 10 & 2.1 & $2.7 \pm 0.21$ & 06 & 2.39 & $2.8 \pm 0.15$ \\
\hline C. zedoaria (5) & 10 & 2.1 & $2.7 \pm 0.14$ & 06 & 2.39 & $2.6 \pm 0.23$ \\
\hline
\end{tabular}

*Defined as the effective dose of plant extract which neutralized venom dose of $2 \mathrm{LD}_{50}$ in vitro/2LD $\mathrm{L}_{50}$ in vivo. Results are expressed as mean of ten observations. ${ }^{* *}$ Duration of deaths time following venom exposure: Ophiophagus hanah venom (1 Minimum lethal dose) $=6.24 \pm 0.20$ hours; Naja kaouthia venom (1 Minimum lethal dose) $=10.68 \pm 0.30$ hours.

Table 4. Neutralization of haemorrhagic action of Daboia russellii and Echis carinatus venom by plant extracts in male albino mice.

\begin{tabular}{|c|c|c|c|c|c|c|}
\hline Extract (mg) & $\begin{array}{l}\text { D. russellii } \\
\text { Venom }(\mu \mathrm{g})\end{array}$ & $\begin{array}{l}\text { Fold of neutralization } \\
\qquad\left(\mathrm{LD}_{50}\right)\end{array}$ & $* \mathrm{ED}_{50}(\mathrm{mg})$ & $\begin{array}{l}\text { E. carinatus } \\
\text { venom }(\mu \mathrm{g})\end{array}$ & $\begin{array}{l}\text { Fold of neutralization } \\
\qquad\left(L_{50}\right)\end{array}$ & $\mathrm{ED}_{50}(\mathrm{mg})$ \\
\hline \multicolumn{7}{|c|}{ Venom extracts incubated $370^{\circ} \mathrm{C} / 60 \mathrm{~min}$ and injected i.v } \\
\hline C. aromatica (2) & 50 & 10 & $0.25 \pm 0.01$ & 30 & 15 & $0.32 \pm 0.01$ \\
\hline A. indica (2) & 40 & 08 & $0.26 \pm 0.01$ & 20 & 10 & $0.35 \pm 0.02$ \\
\hline A. paniculata (2) & 40 & 08 & $0.35 \pm 0.02$ & 20 & 10 & $0.36 \pm 0.02$ \\
\hline C. zedoaria (2) & 30 & 06 & $0.34 \pm 0.01$ & 10 & 05 & $0.45 \pm 0.02$ \\
\hline \multicolumn{7}{|c|}{ Venom injected (s.c) ** followed immediately by extract, p.o. } \\
\hline C. aromatica (5) & 10 & 02 & $2.5 \pm 0.18$ & 14 & 07 & $2.6 \pm 0.18$ \\
\hline A. indica (5) & 05 & 01 & $2.6 \pm 0.22$ & 06 & 03 & $2.8 \pm 0.24$ \\
\hline A. paniculata (5) & 05 & 01 & $2.5 \pm 0.20$ & 06 & 03 & $2.8 \pm 0.10$ \\
\hline C. zedoaria (5) & 05 & 01 & $2.7 \pm 0.16$ & 06 & 03 & $2.9 \pm 0.19$ \\
\hline
\end{tabular}

Defined as the effective dose (ED) of plant extract which neutralized venom dose of 25 MHD in vitro and 1 MHD in vivo. Results are expressed as mean of ten observations. 


\subsection{Coagulant Activity}

The effect of Daboia russellii venom on coagulant activity and their neutralization by plant extract were examined as estimated by plasma recalcification time. The normal value $(0.9 \%$ saline + calcium induced) of minimum clotting dose of plasma (MCDP) was found to be $25 \pm 0.17$ seconds and venom + calcium induced MCDP was found to be $15 \pm 0.20$ second.

The extracts ( $0.2 \mathrm{mg}$ each) were incubated with different amount of venom $(1-75 \mu \mathrm{g})$ and tested for coagulant activity. The venom induced plasma recalcification were antagonized effectively by the plant extracts (Table 5).

\subsection{Serum Inhibitory Activity}

Daboia russellii venom was taken for the serum inhibitory activity. The normal value (calcium-induced) of minimum clotting dose of serum (MCDS) was found to be $25 \pm 0.20$ seconds. The plant extracts (0.2 $\mathrm{mg}$ each) incubated with different amount of venom $(1-75 \mu \mathrm{g})$, antagonized serum inhibitory activity significantly (Table 5).

\subsection{Defibrinogenating Activity}

The methanolic root extract of the plants effectively antagonized the viper venom induced defibrinogenating activity. In in vitro study, the plant extracts (2 mg) gave protection up to 20 MDD against venom-induced defibrinogenation. In in vivo study, venom-induced defibrinogenation was antagonised by the plant extracts. The effective dose of C. aromatica, A. indica, A. paniculata and C. zeodaria was found to be $0.32 \mathrm{mg}, 0.34 \mathrm{mg}, 0.43 \mathrm{mg}$, $0.44 \mathrm{mg}$ respectively in in vitro and $2.4 \mathrm{mg}, 2.6 \mathrm{mg}, 2.5 \mathrm{mg}, 2.5 \mathrm{mg}$ respectively in in vivo of Daboia russellii venom (Table 6 ). The fold of protection was always higher in in vitro studies.

\subsection{Phospholipase Activity}

Phospholipase $\mathrm{A}_{2}$ activity of Daboia russellii venom was assessed by egg yolk coagulation method. One unit of Daboia russellii venom activity was found to be $2 \mu \mathrm{g}$ which increased the coagulation time by one minute (control $0.9 \%$ saline, coagulation time was found to be $45 \pm 1.16$ seconds).

The extracts (C. aromatica, A. indica, A. paniculata and C. zeodaria: $0.2 \mathrm{mg}$ each) were incubated with different amount of viper venom ( $2-100 \mu \mathrm{g}$ ) and tested for phospholipase $\mathrm{A}_{2}$ activity. The venom PLA $\mathrm{A}_{2}$ was effectively neutralized by the plant extracts. The Curcuma aromatic extract $(0.2 \mathrm{mg})$ significantly neutralized the venom $(80 \mu \mathrm{g})$ induced $\mathrm{PLA}_{2}$ activity. The degree of protection was found to be higher in Curcuma aromatic. The effective dose to be $18 \mu \mathrm{g}, 20 \mu \mathrm{g}, 20 \mu \mathrm{g}$ and $20 \mu \mathrm{g}$ by C. aromatica, A. indica, A. paniculata and C. zeodaria respectively (Table 7).

Table 5. Neutralization of coagulant activity of Daboia russellii venom by the plant extracts.

\begin{tabular}{cccc}
\hline Extract $(\mathrm{mg})$ & Venom $(\mu \mathrm{g})$ & Fold of neutralization (in terms of MCDP/MCDS) & ${\text { *Effective dose } \text { ED }_{50}}$ \\
\hline & Venom extracts incubated $370^{\circ} \mathrm{C} / 60$ min added to plasma for MCDP & $20 \pm 1.5$ \\
\hline C. aromatica $(0.2)$ & 75 & 75 & $22 \pm 1.6$ \\
A. indica $(0.2)$ & 50 & 50 & $22 \pm 1.4$ \\
A. paniculata $(0.2)$ & 50 & 50 & $23 \pm 1.3$ \\
C. zedoaria $(0.2)$ & 50 & 50 & $17 \pm 1.6$ \\
\hline C. aromatica $(0.2)$ & 75 & 75 & $19 \pm 1.6$ \\
A. indica $(0.2)$ & 50 & 50 & $22 \pm 1.7$ \\
A. paniculata $(0.2)$ & 50 & 50 & $21 \pm 1.5$ \\
\hline C. zedoaria $(0.2)$ & 50 & 50 & \\
\hline
\end{tabular}

*Defined as the effecting dose of plant extract which neutralized venom dose of 15 MCDP/15 MCDS. Results are expressed as mean of 10 observations. $\mathrm{MCDP}=$ minimum clotting dose plasma; $\mathrm{MCDS}=$ Minimum clotting dose serum. 
Table 6. Neutralization of defibrinogenating activity of Daboia russellii venom by plant extracts in male albino mice.

\begin{tabular}{cccc}
\hline Extract $(\mathrm{mg})$ & Venom $(\mu \mathrm{g})$ & Fold of neutralization (in terms of MDD) & *Effective dose ED $(\mu \mathrm{g})$ \\
\hline C. aromatica (2) & 50 & 20 & $0.32 \pm 0.01$ \\
A. indica (2) & 25 & 10 & $0.34 \pm 0.02$ \\
A. paniculata (2) & 25 & 10 & $0.43 \pm 0.02$ \\
C. zedoaria (2) & 15 & 06 & $0.44 \pm 0.01$ \\
\hline C. aromatica (5) & 3.5 & 1.5 & $2.4 \pm 0.06$ \\
A. indica (5) & 2.5 & 1.0 & $2.6 \pm 0.05$ \\
A. paniculata (5) & 2.5 & 1.0 & $2.5 \pm 0.16$ \\
C. zedoaria (5) & 2.5 & 1.0 & $2.5 \pm 0.20$ \\
\hline
\end{tabular}

* Defined as the effective dose of plant extract which neutralized venom dose of 3 MDD in vitro and 1 MDD in vivo. Results are expressed as mean of 10 observations. MDD minimum defibrinogenating. Dose $=2.5 \mu \mathrm{g}$.

Table 7. Neutralization of Phospholipase A2 activity of Daboiarusselli venom by plant extracts.

\begin{tabular}{|c|c|c|c|}
\hline Extract (mg) & Venom $(\mu \mathrm{g})($ Unit PLA2) & Fold of neutralization (in terms of Unit) & *Effective dose ED $(\mu \mathrm{g})$ \\
\hline \multicolumn{4}{|c|}{ Control (only venom) } \\
\hline Daboia russellii & $2(1)$ & 1 & - \\
\hline \multicolumn{4}{|c|}{ Venom extracts incubated $37^{\circ} \mathrm{C} / 60$ min then added to egg yolk suspension } \\
\hline C. aromatica $(0.2)$ & $80(40)$ & 40 & $18 \pm 1.5$ \\
\hline A. indica $(0.2)$ & $60(30)$ & 30 & $20 \pm 1.6$ \\
\hline A. paniculata $(0.2)$ & $60(30)$ & 30 & $20 \pm 2.0$ \\
\hline C. zedoaria $(0.2)$ & $60(30)$ & 30 & $20 \pm 0.3$ \\
\hline
\end{tabular}

Effective dose of plant extract which neutralized venom dose of 10 units of PLA 2 activity. Results are expressed as mean of ten observations. 1 unit = one unit of enzyme activity of Daboia russelli venom was defined as the amount of venom which increased the coagulation time of egg yolk by one minute.

\subsection{Immunological Interaction of Snake Venom and Plant Extracts}

Immunogel diffusion and immunogel eclectophoresis of snake venom of Daboia russelli, Echis carinatus, Ophiophagus hannah and Naja kaouthia were produced precipitating band with polyvalent antisnake venom antiserum. However venom antigen and plant extract did not produced any precipitating band.

\section{Discussion}

More than hundreds of plants have been used in folk medicine throughout the world for snakebites [14] [15]. Till date few plants/plant materials have been evaluated in well controlled assays and about forty of them have been found to be effective against Cobra and Viper envenomation [2] [16]. In our earlier studies we found that the methanolic root extracts of $H$. indicus, $P$. indica, E. officinalis and $V$. negundo possessed potent anti-snake venom activity [1] [2]. These plant extracts effectively neutralized the snake venom inducing lethal, haemorrhagic, coagulant and anti-coagulant activity both in vivo and in vitro. An organic acid, 2-hydroxy-4-methoxy benzoic acid was isolated, purified from the Indian medicinal plant Hemidesmus indicus root extract, which effectively antagonized the Daboia russelli venom inducing pathophysiological changes both in vitro and in vivo. The mechanism of venom inhibition by the compound was due to free radical formation inhibition through lipoxygenase and cyclo-oxygenase pathway [17]. 
In the present work, four plants out of twenty three plant species were reported for the first time in the Indian context. The plants/plant materials were collected from the traditional healers used in snakebite in the eastern parts of India and were identified by the botanist. In the present investigation the four new plant species which were found active against snake venom were taken for further study. The four plant extracts Aristolochia indica, Andrographis paniculata, Curcuma aromatica and Curcuma zeodaria were effective against snake-venom of Cobra (Naja kaouthia and Ophiophagus hannah) and Viper (Daboia russelli and Echis carinatus) venom both in vivo and in vitro. The maximum fold of protection was found by the methanolic root extract of Curcuma aromatica both in Viper and Cobra venom. The Daboia russellii venom which induced haemorrhagic, coagulant and anticoagulant activities (both in vitro and in vivo) were significantly neutralized by all the four plant extracts.

Of all the plant compounds reported against snake envenomation, the mechanism of action was somehow similar. Some of the plant constituents like coumarin, polyphenols, flavonoids, cinnamic acid derivatives, hydroxyl benzoic acid derivatives, tannins and aristolochic acid have the protein binding and enzyme inhibiting properties [18]. This is due to their affinity to peptides, proteins (enzymes and other toxic components) and metal binding capacity present in the compounds. The PLA $\mathrm{A}_{2}$ enzyme is present in large quantity in almost all the snake venom and has been found to be neutralized by several plant compounds [17] [19] [20].

Curcumin present in Curcuma aromatica may be involved in venom inactivation process. Another unsaturated ketone of turmeric, ar-turmerone was shown to inhibit the lethal action of rattle snake venom [21] [22]. Aristolochia species are famous for snakebite remedies. The aristolochic acid effectively neutralized the viper venom-induced edema [23]. This compound may act through enzyme association and cause significant change in the secondary structure of the snake venom protein. The other chemical compounds present in the plant can be held responsible for the neutralizing effect of snake venom actions [24]. Many compounds identified from plants having different chemical structure were reported to be capable of interacting with peptides and proteins (enzyme) of snake venom. The mechanism of action of the plant extracts/plant compounds are still not clear [25], and they may be attributed to the blocking of receptors-structure prone to chemical attack, and may block the active site of the snake venom. Other mechanism of action of the plant compounds are inhibition of metalloproteinase present in the snake venom. This is due to the metal chellator substances present in the plant extracts/plant compounds. The presence of benzoic acid derivatives and phenolic compounds seem to act through LOX, COX and free radical formation inhibiting systems [17]. This is one of the possible mechanisms of action of venom inhibition. The above evidence may provide some clues of mechanism of venom inhibitions. In our laboratory further work is going on for the identification of pure compound(s) from the plants/plant extracts and their mechanism of venom inhibition.

\section{Acknowledgements}

The authors are obliged to Council of Scientific and Industrial Research, New Delhi, for partial financial support.

\section{References}

[1] Alam, M.I., Auddy, B. and Gomes, A. (1996) Viper Venom Neutralizing by Indian Medicinal Plant (Hemidesmus indicus and Pluchea indica) Root Extract. Phytotherapy Research, 10, 58-61. http://dx.doi.org/10.1002/(SICI)1099-1573(199602)10:1<58::AID-PTR775>3.0.CO;2-F

[2] Alam, M.I. and Gomes, A. (2003) Snake Venom Neutralization by Indian Medicinal Plant (Vitex negundo and Emblica officinalis) Root Extracts. Journal of Ethnopharmacology, 86, 75-80. http://dx.doi.org/10.1016/S0378-8741(03)00049-7

[3] Warrell, D.A. (1995) Clinical Toxicology of Snake Bites in Asia. In: White, M.A., Ed., Handbook of Clinical Toxicology of Animal Venoms and Poisons, CRC Press, Boca Raton, 493-588.

[4] White, J. (2002) Bites and Stings from Venomous Animals: A Global Overview. Therapeutic Drug Monitoring, 22, 65-68. http://dx.doi.org/10.1097/00007691-200002000-00014

[5] Sutherland, S.K. (1977) Serum Reaction. An Analysis of Commercial Antivenom and the Possible Role of Anticomplimentary Activity in De-Novo Reactions to Antivenoms and Antitoxins. Medical Journal of Australia, 1, 613-615.

[6] Corrigan, P., Russel, F.E. and Wainchal, J. (1987) Clinical Reactions to Antivenin. In: Rosenburg, P., Ed., Animal, Plant and Microbial of Toxins, Pergamon Press, New York, 457-464.

[7] Stahel, E., Wellamer, R. and Freyvogel, T.A. (1985) Verzidtongen Durch Einheimische (Viper aviperaberus and Viper 
aaspirise): A Reterospective Studies on 133 Patients. Schweizerische medizinische Wochenschrift, 155, 890-896.

[8] McChesney, J.D. (1995) The Promise of Natural Products for the Development of New Pharmaceuticals and Agrochemicals. In: Seidl, P.R., Gottlieb. O.R. and Kaplan, M.A.C., Eds., Chemistry of the Amazon Symposium Series, America Chemical Society: D.C, 54.

[9] Chopra, R.N., Nayar, S.L. and Chopra, I.C. (1956) Glossary of Indian Medicinal Plants. CSIR Publication, New Delhi, 330.

[10] Nazimudeen, S.K., Ramaswamy, S. and Kameswaran, L. (1978) Effect of Andrographispaniculata on Snake Venom Induced Death and Its Mechanism. Indian Journal of Pharmaceutical Sciences, 40, 132-133.

[11] Theakston, R.D.G. and Reid, H.A. (1983) Development of Simple Standard Assay Procedures for the Characterization of Snake Venom. Bulletin of the World Health Organization, 61, 949-956.

[12] Ouchterlony, O. (1948) In Vitro Methods for Testing the Toxin Producing Capacity of Diphtheria Bacteria. Acta Pathologica Microbiologica Scandinavica, 25, 186-190. http://dx.doi.org/10.1111/j.1699-0463.1948.tb00655.x

[13] Graber, P. and Williams, L.A. (1954) Method for Combined Investigation of Electrophoretic and Immunochemical Properties of a Protein. Biochimica et Biophysica Acta, 10, 193-197.

[14] Houghton, P.J. and Osibogun, I.M. (1993) Flowering Plant Used against Snakiebite. Journal of Ethnopharmacology, 39, 1-29. http://dx.doi.org/10.1016/0378-8741(93)90047-9

[15] Samy, R.P., Thwin, M.M., Gopalkrishnakone, P. and Ignacimuthu, S. (2008) Ethnobotanical Survey of Folk Plants for the Treatment of Snakebites in Southern Part of Tamilnadu. Journal of Ethnopharmacology, 115, 302-312. http://dx.doi.org/10.1016/j.jep.2007.10.006

[16] Martz, W. (1992) Plants with Reputation against Snakebite. Toxicon, 30, 1131-1142. http://dx.doi.org/10.1016/0041-0101(92)90429-9

[17] Alam, M.I., Auddy, B. and Gomes, A. (1998) Viper Venom Induced Inflammation and Inhibition of Free Radical Formation by Pure Compound (2-hydroxy-4-methoxy Benzoic Acid) Isolated and Purified from Anantamul (Hemidesmus indicus R.Br.) Root Extract. Toxicon, 36, 207-215. http://dx.doi.org/10.1016/S0041-0101(97)00070-6

[18] Alcaraz, M.J. and Hoult, J.R.S. (1985) Effect of Hypolaetin-8-Glucoside and Related Flavonoids on Soybean Lipooxygenase and Snake Venom Phospholipase $\mathrm{A}_{2}$. Archives Internationales de Pharmacodynamie et de théRapie, 278, 412.

[19] Gowda, T.V. (1997) Intereaction of Snake Venom Phospholipase A2 with Plant Isolates. Chapter 8. In: Kini, R.M., Ed., Venom Phosphlipse A2 Enzyme: Structure, Function and Mechanism, John Wiley \& Sons, Ltd., New York, 205-222.

[20] Melo, P.A. and Ownby, C.L. (1999) Ability of Wedelolactone, Heparin and para-bromophenacyl Bromide to Antagonize the Myotoxic Effects of Two Crotalide Venoms and Their PLA 2 Myotoxins. Toxicon, 37, 199-215. http://dx.doi.org/10.1016/S0041-0101(98)00183-4

[21] Ferreira, L.A.F., Henriques, O.B., Anderoni, A.A.S., Viotal, G.R.F., Campos, M.M.C., Habermehl, G.G. and Moraes, V.L.G. (1992) Antivenom and Biological Effects of Ar-Tumerone Isolated from Curcuma longa (Zingeberaceae). Toxicon, 30, 1211-1218. http://dx.doi.org/10.1016/0041-0101(92)90437-A

[22] Mendes, M.M., Vieira, S.A.P.B., Gomes, M.S.R., Paula, V.F., Alcantara, T.M., Homsi-Brandeburgo, M.I., Dos Santos, J.I., Margo, A.J., Fontes, M.R.M. and Rodrigues, V.M. (2013) Triaconyl p-Coumarate: An Inhibitor of Snake Venom Metalloproteinases. Phytochemistry, 86, 72-82. http://dx.doi.org/10.1016/j.phytochem.2012.10.007

[23] Tsai, L.H., Yang, L.L. and Chang, C. (1980) Inactivation of Formosan Snake Venoms in Vivo by Aristolochic Acid, the Chemical Component of Aristolochia Radix. Formosan Science, 34, 40-44.

[24] Mors, W.B., Nascimento, M.C., Bettina, M., Ruppelt, P. and Pereira, N.A. (2002) Plant Natural Product Active against Snakebite-The Molecular Approach. Phytochemistry, 55, 627-642. http://dx.doi.org/10.1016/S0031-9422(00)00229-6

[25] Dufton, M.J. and Hider, R.C. (1980) Lethal Protein Conformations. Trends in Biochemical Sciences, 5, 53-56. http://dx.doi.org/10.1016/S0968-0004(80)80097-1 
Scientific Research Publishing (SCIRP) is one of the largest Open Access journal publishers. It is currently publishing more than 200 open access, online, peer-reviewed journals covering a wide range of academic disciplines. SCIRP serves the worldwide academic communities and contributes to the progress and application of science with its publication.

Other selected journals from SCIRP are listed as below. Submit your manuscript to us via either submit@scirp.org or Online Submission Portal.
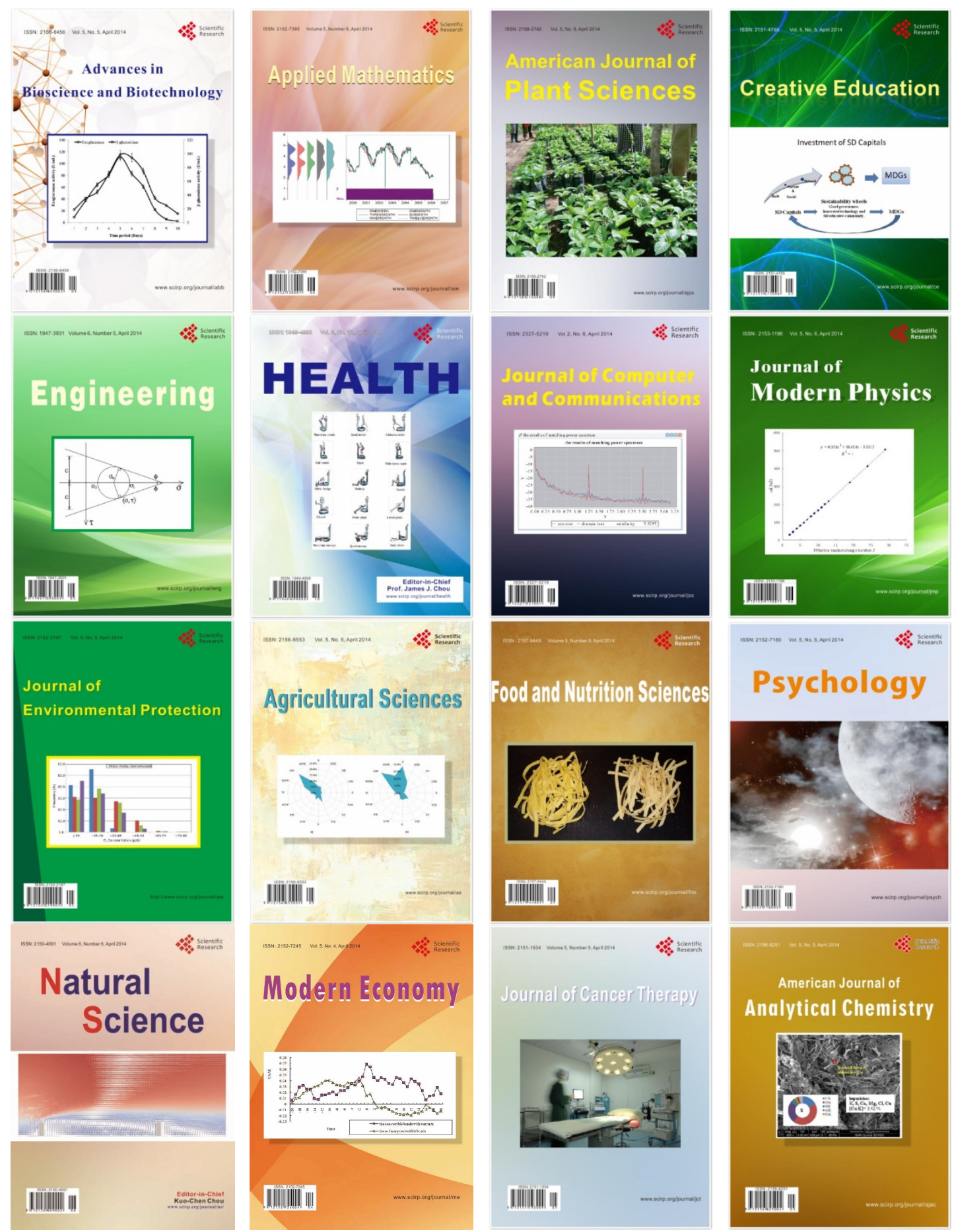